\title{
State of knowledge of the tachinid fauna of Eastern Asia, with new data from North Korea. Part III. Phasiinae. Supplement
}

\author{
Agnieszka DRABER-MoŃKO \\ Museum and Institute of Zoology,PAS, Wilcza 64,00-679Warszawa; e-mail: draber@miiz.waw.pl
}

\begin{abstract}
Additions are made to the "State of knowledge of the tachinid fauna of Eastern Asia, with new data from North Korea. Part I. Phasiinae"(Draber-Monko 2008). Seven species of the phasiine flies representing five genera were identified in the material. Six species are reported for the first time in the fauna of Korea. Two of them: Calyptromyia barbata Villeneuve, and Parerigone tianmushana Chao et Sun are presented in colour images. At present twenty three species of the phasiine flies are recorded from the Korean Peninsula.
\end{abstract}

Key words: Diptera, Tachinidae, supplement to Phasiinae, North Korea

\section{INTRODUCTION}

The present paper is a supplement to earlier papers on the Tachinidae collected by Polish expeditions to North Korea (Draber-Mońko 2008, 2011). In the first part of the paper on the Phasiinae (Draber-Mońko 2008) thirteen species of this subfamily were identified and most of them (10 species) had been previously unknown from the territory of Korea. Two new species are described and illustrated: Dionaea karinae Draber-Mońko and Hemyda dominikae Draber-Mońko. The first part also contains a discussion of the present state of knowledge of the Phasiinae fauna of the Far East and a rich list of relevant papers concerned with this region.

Since the first publication concerning the Korean Phasiinae (Draber-Mońko 2008), ten undetermined specimens of the phasiine flies have been found in the collections of the Museum and Institute of Zoology PAS. However, because of poor knowledge of this group of Diptera in Eastern Asia, including Korea, the material has been studied. Consequently, in spite of the fact that the material collected in North Korea by researchers from the Institute of Zoology PAS is fairly scanty, nowadays, twenty three species belonging to eleven genera of the phasiine flies are known from Korea.

\section{MATERIAL AND METHODS}

The phasiine flies were collected during six expeditions to North Korea: in 1959, 1965, 1966, 1970, 1987 and in 1990. Detailed descriptions of these expeditions are in Mroczkowski (1972) and to Bańkowska \& Sterzyńska (1997). The locations of the sampling areas in North Korea are presented in Fig. 1 in the paper of Draber-Mońko (2008).

The scanty material of the Phasiinae, considered here, includes 10 specimens collected with a sweeping net. They represent seven species belonging to five genera of the phasiine flies. Six of them had been previously unknown from the Korean Peninsula. The current list was supplemented by four species mentioned by other authors (Kim 1981, 1996, Cha \& Han 2009).

The systematic arrangement of the present paper follows that provided by Tschorsnig \& Richter (1998) and Richter (2004), O'Hara, Shima \& Zhang (2009) and Shima (2011). 


\section{Subfamily Phasiinae}

Tribe Cylindromyiini

Cylindromyia Meigen, 1803

Cylindromyia (Calocyptera) Herting, 1983

\section{Cylindromyia (Calocyptera) intermedia (Meigen, 1824)}

Ocyptera intermedia Meigen, 1824: 212. Type locality: not given (probably Europe)

Ocyptera scalaris Loew, 1844: 240. Type locality: Austria, Wien [= Vienna]

Ocyptera reinigi Enderlein, 1934: 132. Type locality: Tadzhikistan, Pamir, Kara-su.

Material examined: North Korea, Kangvŏn-do Prov., Vŏnsan, hill-side, 30.08.1987, 1 male, leg. J. Sawoniewicz.

Distribution: Palaearctic: Europe: Mediterranean region, northwards to Poland (warmer parts of Europe), Middle East, Transcaucasia, Uzbekistan, Tadzhikistan, Iran, Mongolia, Russia: European part of Russia, S Siberia (Altai, Tuva, Chita), Russian Far East (Ussuria), China (Hebei Prov., Heilongjiang Prov., Inner Mongolia, Xinjiang Uygur Autonomous Region), Nearctic Region: widespread from North Canada to California and Texas (Herting 1983, Richter 2004, O’Hara et al 2009). First record from Korea.

Cylindromyia (Malayocyptera) Townsend, 1926

\section{Cylindromyia (Malayocyptera) agnieszkae Kolomyetz, 1977}

Cylindromyia (Malayocyptera) agnieszkae Kolomyetz, 1977: 53. Type locality: Russian Far East: Primorie, Ussuriysk

Material examined: North Korea, Phjŏngan-pukto Prov., Hjangsan distr., Mjohjang Mts, Hjangsan, near hotel, pine scrub, 21.08.1987, 1 male, leg. J. Sawoniewicz.

Distribution: Palaearctic: Asia, Russian Far East (Primorie) (Kolomyetz 1977, Ziegler \& Shima 1996, Richter 2004), N Korea, Chŏngdžin-si Prov., (Kolomyetz 1977, Draber-Mońko 2008), Kesŏng-si Prov. (Herting 1983).

Tribe Leucostomatini

Calyptromyia Villeneuve, 1915

\section{Calyptromyia barbata Villeneuve, 1915 (Figs 1-4)}

Calyptromyia barbata Villeneuve, 1915: 92. Type locality: Taiwan, Kaohsiung Hsien, Chiahsien Hsiang [as "Kosempo" (Formosa)].

Material examined: North Korea, Phjŏngjang-si Prov., Phjŏngjang City, Taesong-san Park, 1.09.1987, 1 male, leg. E. Kierych.

Distribution: Palaearctic: Russian Far East (S Primorie Yakovlevka 55 km ESE of SpasskDalniy), Japan (Honshū, Shikoku, Kyūshū, Tsushima), China Provinces: Anhui, Fujian, Zhejiang. Oriental: Taiwan, China (Hainan Prov.), Vietnam (Richter 1993, 2004, Shima 1999, O'Hara, Shima \& Zhang 2009). First record from Korea.

Note: Among the specimens examined I found a male belonging to the Calyptromyia barbata Villeneuve, 1915 (after the Key to the insects of Russian Far East. Vol. VI. Diptera and Siphonaptera. Pt 3. pp. 148-398. Vladivostok. 2004. 124. Fam. Tachinidae. V. A. Richter: 387-388). This specimen lacked the head and therefore I am not sure of my identification. I 
sent photographs of the Korean specimen to Professor Hiroshi Shima with a kind request to compare them with the Japanese specimen of $C$. barbata Villneuve. After making the comparison Professor H. Shima stated the following: "Yes, I think your specimen is a male of Calyptromyia barbata Villeneuve. It exhibits the characteristic features of the strong male cerci, wing vein $\mathrm{M}_{1}$ with an appendage at its bend, large lower calypter and black body. These correspond well with the characteristics of C. barbata".
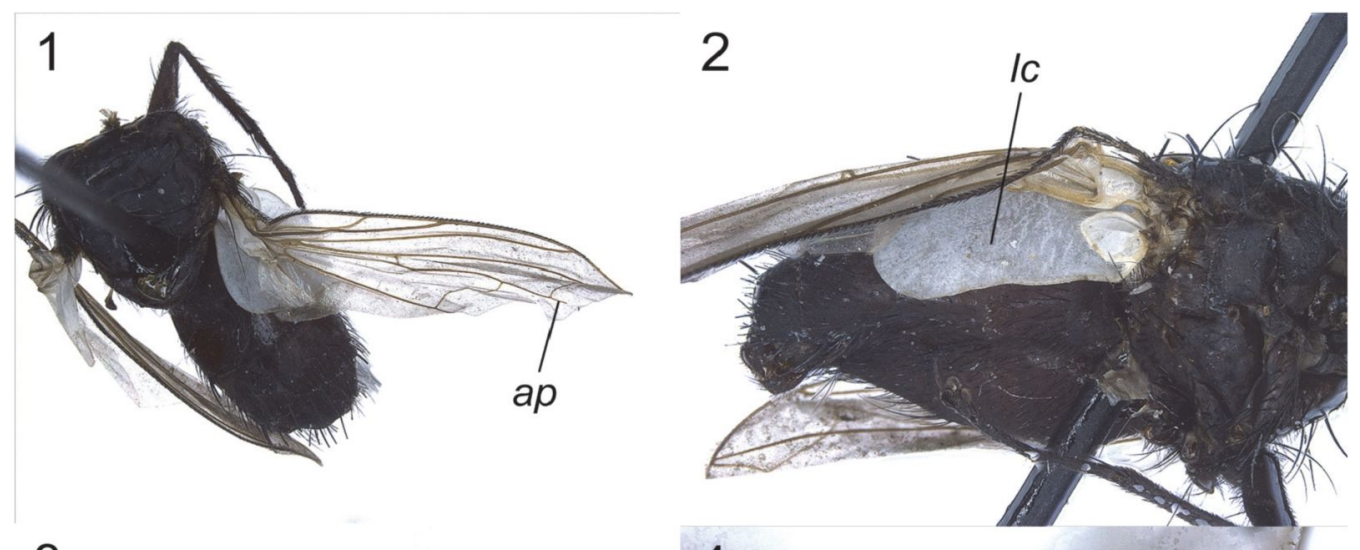

3

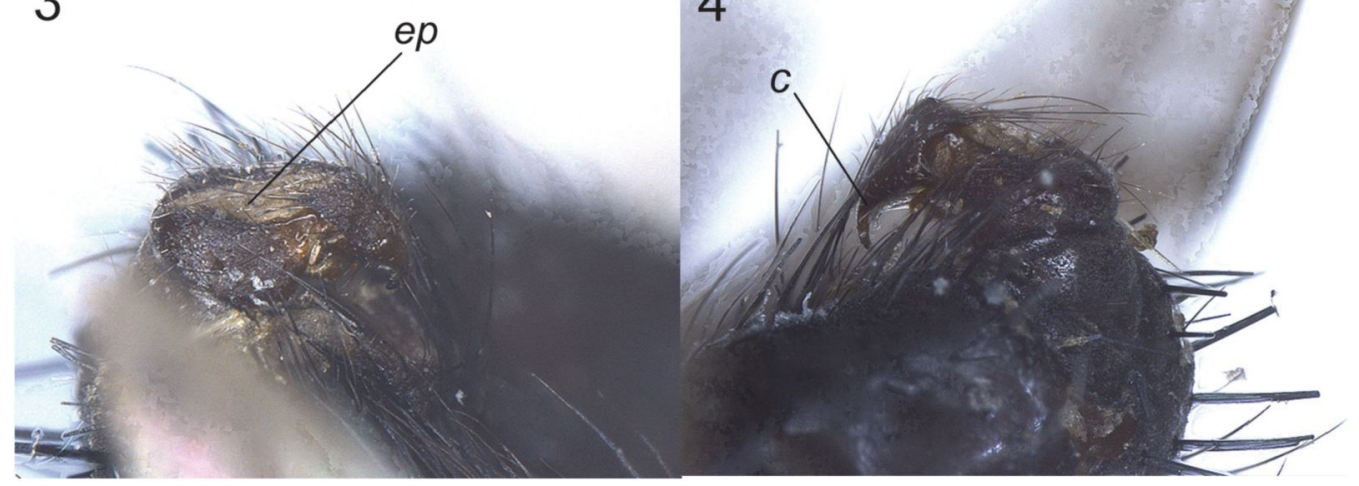

Figs 1-4. Calyptromyia barbata Villeneuve, male, North Korea, Phjŏngjang-si Prov., Phjŏngjang City, Taesong-san Park, 1.09.1987, 1 male, leg. E. Kierych (photo P. Ślipiński); 1 - habitus in dorsal view, ap - appendage of $\mathrm{M}_{1}, 2-$ habitus in lateral view, $l c$ - lower calypter, 3 - abdomen in ventral view, $e p$ - epandrium, 4 - postabdomen in back view, $c$ - cerci.

\section{Clelimyia Herting, 1981}

\section{Clelimyia paradoxa Herting, 1981}

Clelimyia paradoxa Herting, 1981: 15. Type locality: Japan, Minano, Saitama, Honshū.

Material examined: North Korea, Phjŏngan-pukto Prov., Hjangsan distr., Mjohjang Mts, Hjangsan, near hotel, pine scrub, 21.08.1987, 1 male, leg. J. Sawoniewicz.

Distribution: Palaearctic: Russian Far East (Amur Prov., Primorsk Territory), Japan (Honshū) (Herting 1981, 1984, Herting and Dely-Draskovits 1993, Richter 1986). First record from Korea. 

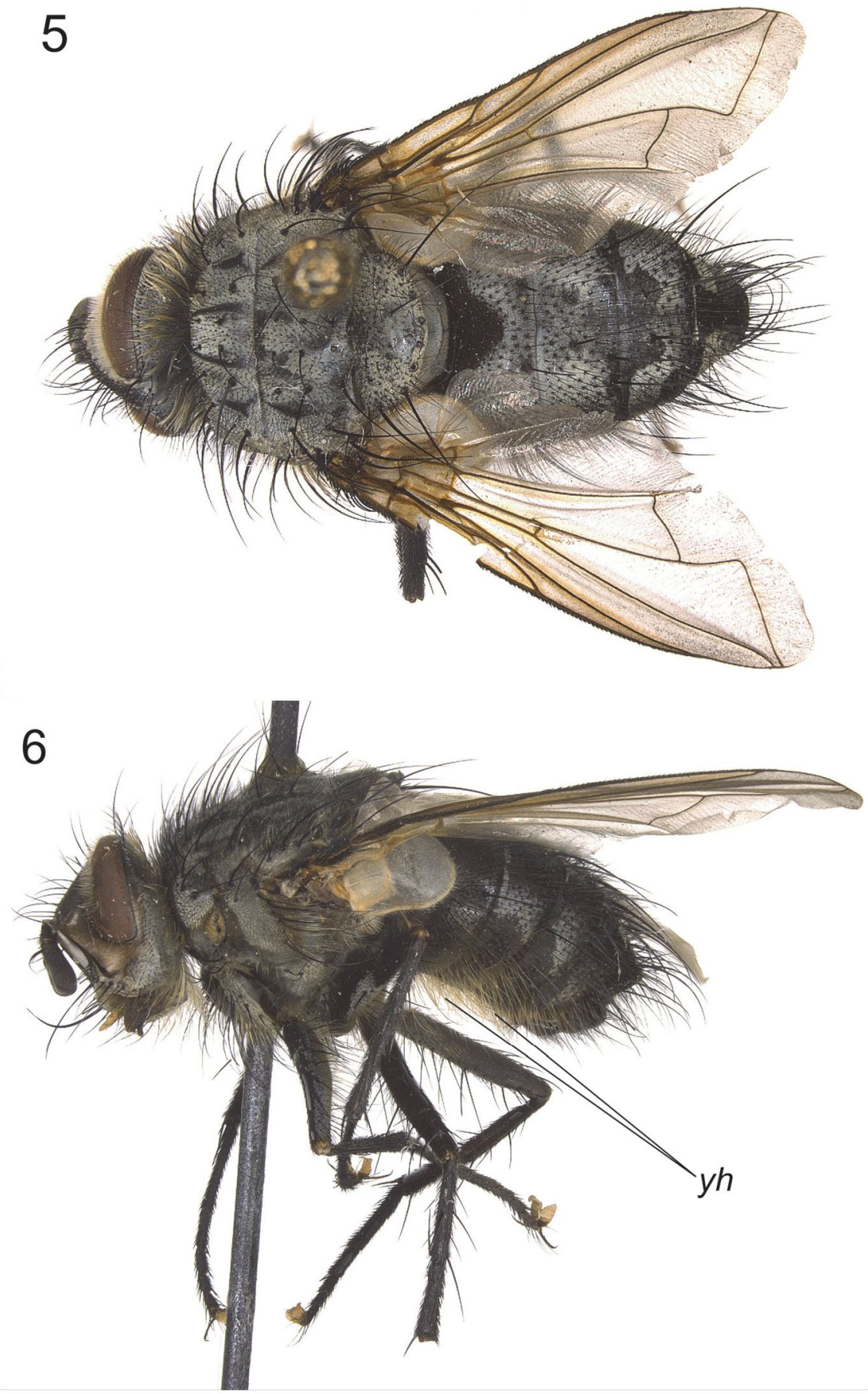

Figs 5-6. Parerigone tianmushana Chao et Sun, male, North Korea, Phjŏngjang-si Prov., Taesŏng-san Park, 6.06. 1990, 4 males, leg. E. Chudzicka, E. Kierych and R. Pisarska (photo P. Ślipiński); 5 - habitus in dorsal view; 6 habitus in lateral view, $y h$ - yellow hairs on ventral side. 


\section{Dionaea flavisquamis Robineau-Desvoidy, 1863}

Dionaea flavisquamis Robineau-Desvoidy, 1863: 57. Type locality: France.

Dionaea aurulans: Dupuis, 1973: 373. Type locality: not given (probably France). Not Robineau-Desvoidy, 1830, misidentification.

Material examined: North Korea, Phjŏngan-pukto Prov., Hjangsan distr., Mjohjang Mts, Hjangsan, xerothermic plants on the bottom of a river, 18.08.1987, 1 female, leg. J. Sawoniewicz.

Distribution: Palaearctic: Europe: France, Germany, Swiss (Herting 1977, 1984), W Kazakhstan (Richter 2005). First record from Korea.

\section{Dionaea magnifrons Herting, 1977}

Dionaea magnifrons Herting, 1977: 14. Type locality: France, Lagnes, Vaucluse.

Material examined: North Korea, Phjŏngan-pukto Prov., Hjangsan distr., Mjohjang Mts, Hjangsan, xerothermic plants on the bottom of a river, 18.08.1987, 1 male, leg. J. Sawoniewicz.

Distribution: Palaearctic: Europe: S France, Asia: Japan (Honshū, Kyūshū) (Herting 1984, Herting \& Dely-Draskovits 1993). First record from Korea.

Tribe Parerigonini

Parerigone Brauer, 1898

\section{Parerigone tianmushana Chao et Sun, 1990 (Figs 5-6)}

Parerigone tianmushana Chao et Sun in Chao, Sun et Zhou, 1990: 231. Type locality: China, Zhejiang Prov., Tianmu Shan [as "Mt. Tianmu"]

Material examined: North Korea, Phjŏngjang-si Prov., Taesŏng-san Park, 6.06.1990, 4 males, leg. E. Chudzicka, E. Kierych and R. Pisarska.

Distribution: Palaearctic: China (Shaanxi Prov., Zhejiang Prov.) (Shima 2011). First record from Korea.

Note: Chao \& Sun in their paper of 1990 on page 240 wrote: "The new species [(Parerigone tianmushana Chao et Sun) my addition] is closely related to Parerigone aurea B., but may be distinguished by the tibia in black unicolor, dorsal surface of the thorax with black hairs; in male the top of surstylus turning back ventrally and hook-shaped in lateral view". Shima published, in 2011 an important paper on the genus Parerigone Brauer and there in the key to the known species of Parerigone Brauer he provided more characteristics distinguishing Parerigone tianmushana Chao et Sun from the other species in this genus.

Tribe Phasiini

Phasia Latreille, 1804

\section{Phasia albopunctata (Baranov, 1935)}

Alophora albopunctata Baranov, 1935: 559. Type locality: Japan, Hokkaidō, Sapporo.

Distribution: Palaearctic: South Korea (Kim 1996 as Alophora albopunctata Baranov), Russia (West and East Siberia, Russian Far East), Japan (Hokkaidō), Oriental Region: Taiwan, Pakistan (O’Hara, Shima \& Zhang 2009). 


\section{Phasia aurigera (Egger, 1860)}

Alophora aurigera Egger, 1860: 796. Type locality: Austria, Wien.

Distribution: Palaearctic: South Korea (Cha and Han 2009), West, East and South Europe, Russia (Southern Far East), China (Beijing Municipality Prov., Jilin Prov., Sichuan Prov.) (O’Hara, Shima \& Zhang 2009).

\section{Phasia hemiptera (Fabricius, 1794)}

Syrphus hemipterus Fabricius, 1794: 284. Type locality: United Kingtom, England [as "Angliae"].

Distribution: Palaearctic: South Korea (Kim 1981 as Phasia vittata Girschner), Europe (all), Russia (all), Transcaucasia, Japan (Hokkaidō, Honshū, Shikoku, Kyūshū), China (Beijing Municipality Prov., Heilongjiang Prov.) (O’Hara, Shima \& Zhang 2009).

\section{Phasia takanoi (Draber-Mońko, 1965)}

Alophora (Brumptallophora) takanoi Draber-Mońko, 1965: 147. Type locality: Russian Far East (Sudzukh).

Distribution: Palaearctic: Russian Far East, South Korea, Japan (Cha and Han 2009).

\section{ACKNOWLEDGEMENTS}

I should like to express my most cordial thanks to Prof. Hiroshi Shima (Kyushu University Museum, Hakozaki, Fukuoka, Japan) for comparing my photographs of the male from North Korea with the Japanese Calyptromyia barbata Villeneuve.

I wish also to thank very much to Mr Piotr Ślipiński, MSc. Eng., for taking the photographs. My special thanks are due to Mr Tomasz Karolkiewicz for the digital preparation of the figures.

The author is very grateful to two anonymous reviewers for their valuable comments.

\section{REFERENCES}

BAŃKOWSKA R. \& STERZYŃSKA M. 1997. Faunistic investigations conducted in North Korea by researchers from the Institute of Zoology Polish Academy of Sciences from 1959 to 1990. Fragmenta Faunistica, 40: $247-253$.

DRABER-MONKO A. 2008. State of knowledge of the tachinid fauna of Eastern Asia, with new data from North Korea. Part I. Phasiinae. Fragmenta Faunistica 51: 119-137.

DRABER-MONKO A. 2011 . State of knowledge of the tachinid fauna of Eastern Asia, with new data from North Korea. Part II. Tachininae. Fragmenta Faunistica 54: 157-177.

CHA D. J. \& HAN H. Y. 2009. Two Species of the Genus Phasia Latreille (Insecta: Diptera: Tachinidae) New to Korea. Korean Journal of Systematic Zoology 25: 309-316.

CHAO C.-M., SUN X.-K. \& ZHOU S. 1990. Studies on the tribe Parerigonini from China (Diptera: Phasiinae). Acta Zootaxonomica Sinica, 15: 230-241.

HERTING B. 1981. Typenrevisionen einiger paläarktischer Raupenfliegen (Dipt. Tachinidae) und Beschreibungen neuer Arten. Stuttgarter Beiträge zur Naturkunde. Serie A (Biologie) No. 346: 1-21.

HERTING B. 1983. 64. Phasiinae. In: LINDNER E. (ed.): Die Fliegen der palaearktischen Region 9: 1-88. Stuttgart: E. Schweitzerbart'sche Verlagbuchhandlung.

HeRtTNG B. 1984. Catalogue of Palearctic Tachinidae (Diptera). Stuttgarter Beiträge zur Naturkunde. Serie A (Biologie) No. 369: 1-228.

Herting B. \& Dely-Draskovits Á.1993. Family Tachinidae.Vol.13, pp. 118-458. In: Soós (ed.), Á. Catalogue of Palaearctic Diptera, Anthomyiidae - Tachinidae. Hungarian Natural History Museum, Budapest, 624 pp.

KIM J. I. 1981. The faunistic study on the insects from Sudong-myeon, Namyangju-gun, Gyeonggi-do, Korea. Bulletin of the Korean Association for Conservation of Nature, Series III, pp. 329-367.

KIM J. I. 1996. Insects fauna of Coleoptera and Diptera from Mt. Pangtae in summer season. Department of Biology, Sungshin Women's University, 35: 163-180.

Kolomyetz N. G. 1977. New data on the parasitic Diptera Phasiinae from Siberia and the Far East. Izvestija Sibirskogo Otdelenija Akademii Nauk SSSR, 3: 52-55. [In Russian] 
MRoczKowskI M. 1972. Field Investigations in the Democratic People's Republic of Korea by staff members of the Institute of Zoology of the Polish Academy of Sciences. Fragmenta Faunistica 18: 313-331.

O'HARA J., SHIMA H. \& ZHANG C. 2009. Annotated Catalogue of the Tachinidae (Insecta: Diptera) of China. Zootaxa, 2190: 1-236.

RICHTER V. A. 1986. On the fauna of tachinids (Diptera, Tachinidae) of the Far East. [In Russian] USSR Academy of Sciences, Proceedings of the Zoological Institute, Leningrad, 146: 87-116. [In volume entitled "Flies (Diptera) in ecosystems of South Siberia and Far East", ed. by E. P Nartshuk.]

RICHTER V. A. 1993. New and little known tachinids (Diptera, Tachinidae) of Transbaikalia and Far East. Entomologicheskoe Obozrenie, 72: 422-440. [In Russian]

Richter V. A. 2004. Fam. Tachinidae - tachinids. In: Sidorenko V.S. (ed.), Key to the insects of Russian Far East. Vol. VI. Diptera and Siphonaptera. Part 3. Pp. 148-398. Vladivostk, Dal'nauka. 657 pp. [In Russian]

RICHTER V. A. 2005. New data on the biology and distribution of Palaearctic Tachinids (Diptera, Tachinidae). Entomologicheskoe Obozrenie, 84: 911-915. [In Russian]

SHIMA H. 2011. Notes on Parerigone with a description of a bew species from Nepal (Diptera: Tachinidae). Entomological Society of Canada 143: 674-687.

Tschorsnig P.H. and RICHTER V. A. 1998. 3.54. Family Tachinidae, pp. 691-827. In: PAPP L. \& DARVAS B. (eds), Contributions to a Manual of Palaearctic Diptera (with special references to flies of economic importance). Volume 3. Higher Brachycera. Science Herald, Budapest. 880 pp.

ZIEGLER J. \& SHIMA H. 1996. Tachinid flies of the Ussuri area (Diptera: Tachinidae). Contributions to the knowledge of East Palaearctic insects (5). Beiträge zur Entomologie 46: 379-478.

\section{StreszczenIE}

\section{[Stan wiedzy o faunie rączyc Azji Wschodniej z uwzględnieniem nowych danych z Korei Pólnocnej. Część III. Phasiinae. Uzupelnienie]}

Opracowanie stanowi kontynuację badań nad fauną rączyc Korei Pólnocnej. Materiał został zebrany przez pracowników Instytutu Zoologii PAN w Warszawie w latach 1959-1990, podczas wypraw do Korei Północnej. Muchówki były zbierane siatką entomologiczną. Zidentyfikowano 7 gatunków Phasiinae zaliczanych do 5 rodzajów, 6 gatunków odnotowuje się tu po raz pierwszy z Półwyspu Koreańskiego. Dwa rzadko wykazywane i nowe dla fauny Korei gatunki rączyc Calyptromyia barbata Villeneuve, 1915 oraz Parerigone tianmushana Chao et Sun, 1990 przedstawiono na kolorowych fotografiach. Drugi z gatunków znany byl tylko z locus typicus i jeszcze jednego miejsca w Chinach, więc stanowisko w Korei jest trzecim stwierdzeniem tego gatunku na świecie. Obecnie w faunie Półwyspu Koreańskiego znane są 23 gatunki Phasiinae zaliczane do 11 rodzajów. 